\title{
Experimental Investigation of Granular Activated Carbon/R-134a Pair for Adsorption Cooling System Applications
}

\author{
M. Attalla*, S. Sadek \\ Mechanical Power Department, Faculty of Engineering, South Valley University, Qena, Egypt. \\ Email: *moha attalla@yahoo.com
}

Received January $6^{\text {th }}, 2014$; revised February $6^{\text {th }}, 2014$; accepted February $14^{\text {th }}, 2014$

Copyright (C) 2014 M. Attalla, S. Sadek. This is an open access article distributed under the Creative Commons Attribution License, which permits unrestricted use, distribution, and reproduction in any medium, provided the original work is properly cited. In accordance of the Creative Commons Attribution License all Copyrights (C) 2014 are reserved for SCIRP and the owner of the intellectual property M. Attalla, S. Sadek. All Copyright (C) 2014 are guarded by law and by SCIRP as a guardian.

\begin{abstract}
The objective of this study is to investigate the adsorption characteristics of granular activated carbon GAC/R134a pair in the temperature range of $20^{\circ} \mathrm{C}-60^{\circ} \mathrm{C}$ and pressure up to 10 bars. The Dubinin-Astakhov adsorption equilibrium model is fit to experimental data with acceptable error limit. The pressure-temperature-concentration (P-T-X) diagram of the pair is also presented. The isosteric heat of adsorption of R-134a on activated carbon has been calculated using the Clausius-Clapeyron equation as a function of adsorption capacity. The maximum adsorption capacity was found to be $1.92 \mathrm{kgR} 134 \mathrm{a} / \mathrm{kg}$ carbon at $20^{\circ} \mathrm{C}$ after $1200 \mathrm{~s}$. The experimental results also show that the increase of heat transfer area improves the adsorption capacity per $\mathrm{kg}$ of adsorber, which leads to the design of a finned tubes heat exchanger adsorption unit.
\end{abstract}

\section{KEYWORDS}

Adsorption; Activated Carbon; R-134a; Isosteric Heat

\section{Introduction}

Over the past two decades, adsorption refrigeration system has gained considerable interest due to its ability to combat ozone depletion problem that was caused by the utilization of CFCs and HCFCs in cooling system [1,2]. The thermo-physical properties of adsorbent/refrigeration pairs as well as the operating conditions have significant effects on the system performance [3,4]. The adsorption cooling and refrigeration systems have many advantages of being compact, free moving parts, and free of toxic and environmentally harmful materials and need low temperature to work, and don't require synthetic lubrication $[5,6]$. It is a matter of regret that absorption data are unavailable from the manufactures of adsorbents $[7,8]$.

Just the data of surface area and pores volume of the adsorbent are available which are insufficient to design a thermally driven adsorption system $[9,10]$. The design adsorption based cooling cycle is inevitable to evaluate

\footnotetext{
*Corresponding author.
}

adsorption isotherms of the assorted adsorbent/adsorbate pairs as well as the isosteric heat of adsorption.

The selection of any pair of adsorbent/adsorbate for refrigeration applications depends on certain desirable characteristics ranging from their thermodynamic and chemical properties to their physical properties and even to their costs or availability [11]. The debate is on whether to continue with hydro fluorocarbon (HFC) refrigerants or if a time has come to switch fully to natural refrigerants such as ammonia and carbon dioxide [12]. In addition, the even flammable hydro fluorocarbon is gaining prominence in the wake of global warming issue that is rocking the world. Hydro fluorocarbon (HFC-134a) is considered friendly refrigerant on ozone layer. Therefore, all countries will continue developing it at least for the next two decades [12].

The following are some representative examples of thermally driven adsorption systems. Akkimaradi et al. [13] measured adsorption isotherms of R-134a on three types of activated carbons namely Chemviron, Fluka and 
Maxsorb II. Askalany et al. [11] estimated adsorption characteristics of granular activated carbon/R-134a pairs. Pons and Guilleminot [14] designed and tested an activated carbon-methanol icemaker driven by solar heat. It was observed that the coefficient of performance (COP) of icemaker is 0.15 . Wang et al. [8] studied the adsorption characteristics of ACF/methanol and activated carbon (AC)/methanol pairs. They showed that the coefficient of performance of ACF/methanol pair is about 10 20 percent higher than that of AC/methanol pair. Vasiliev et al. [15] and Vasiliev [16] developed the adsorption heat pump with activated carbon fiber as an adsorbent and ammonia as the working fluid. They explained the effect of adsorbent material, which combined activated carbon fiber and some salts on adsorption capacity. The full adsorption capacity of the activated carbon fiber methanol system reaches up to $0.55 \mathrm{~kg}$ of methanol $/ \mathrm{kg}$ of ACF. Banker et al. [17] introduced a mathematical model for activated carbon R-134a pair based two-stage thermal compression adsorption refrigeration using low-grade thermal energy sources. It derived a COP of 0.16 for the system. In addition, they showed that the system achieved low COP of less than 0.04 at $0.93^{\circ} \mathrm{C}$ driving source temperatures in another study [18].

Enhancement of heat and mass transfer in the adsorber/desorber heat exchanger is the most important factor to improve the system COP [9]. There are two major points for the achievement of heat and mass transfer enhancement. First is to improve heat and mass transfer mechanically between adsorbent bed and the surface of the heat transfer material, such as extended heat transfer. The second point is to develop new adsorbent material having highly uptake and adsorption rate. Chang et al. [19] used flat-tube type heat exchangers for adsorption beds to increase the heat transfer area and improve the heat transfer ability between the adsorbent and heat exchanger fins. The study was conducted under the standard test conditions of $80^{\circ} \mathrm{C}$ hot water, $30^{\circ} \mathrm{C}$ cooling water, and $14^{\circ} \mathrm{C}$ chilled water inlet temperatures. It has provided a specific cooling power (SCP) of about $176 \mathrm{~W} /(\mathrm{kg}$ adsorbent). Watanabe et al. [20] investigated the possibility of producing cold energy by a super active carbon SAC/ethanol adsorption system with a packed bed type adsorber. The SAC/ethanol adsorber system enables to increase the heat transfer fluid operating temperature range, while the amount of cooling energy production is the same as the conventional silica gel-water based adsorption system [9,21]. Ito et al. [22] made an adsorber heat exchanger composed of a consolidated bed of silica gel particles to enhance heat transfer. They reported the feasibility of adsorption refrigeration operating using the consolidated bed heat exchanger.

From the above perspective, this study investigated the adsorption characteristics of GAC/R-134a Pairs for cool- ing system applications. A circular tube heat exchanger with fins was adopted as an adsorber bed. Adsorption isotherms of R-134a on granular activated carbon were measured within the temperature from $20^{\circ} \mathrm{C}$ to $75^{\circ} \mathrm{C}$. The instantaneous capacity of R-134a has been recorded at each $60 \mathrm{~s}$ under constant volume, constant temperature and variable pressure. In addition, the Dubinin-Astakhov (D-A) equation was used to model equilibrium data of the adsorption and desorption experiments. The present data are compared with those of Saha et al. [5] and Askalany et al. [11].

\section{Experimental Section}

\subsection{Materials}

Adsorption technology can be used for not only air conditioning and refrigeration but also for upgrading heat with thermal transformers, and the type of refrigerant should be selected according to the application [4]. The requirements for a suitable refrigerant are generally as follows: 1) high latent heat of vaporization, 2) thermal stability, 3) environmental harmless, 4) inflammability, 5) innoxiousness and 6) saturation pressure between 1 and 5 atm in working temperature $[4,23]$. Unfortunately, there are no refrigerants that have all the characteristics shown above. The refrigerant R134a of 99.9\% purity has been used in the present study and supplied by Foshan Liangyou Environmental Protection Chemicals Co., Ltd China. All properties of R134a used in this paper were evaluated from REFPROP7 software, which is based on the generalized equation of state proposed [5,24].

The activated carbon is made of materials such as wood, peat, coal fossil oil, chark, bon coconut shell and nut stone $[4,23]$. The microcrystal for the activated carbon product from bon is a six-element carboatomic ring, [23]. While the adsorption performance is influenced by the functional group that increases adsorption, as sulfonic group decreases it $[25,26]$. Acidic functional group increases adsorption selectivity. The functional groups on the surface of activated carbon are different if the original carbonaces material and activation method are differrent [4]. The specific area of activated carbon is between 500 and $1500 \mathrm{~m}^{2} / \mathrm{kg}$ [4]. Table 1 shows the thermo-physical properties of granule activated carbon [11,12].

\subsection{System Description}

The schematic diagram of the experimental setup of adsorption test unit is illustrated in Figures 1(a) and (b). The experimental setup includes two systems. One is the heating system; the other is the cooling system. The heating system includes an electric heater capacity range from $1.75 \mathrm{~kW}$ to $4 \mathrm{~kW}$ is used to drive the system by heating intermediate water. Circulating the intermediate 


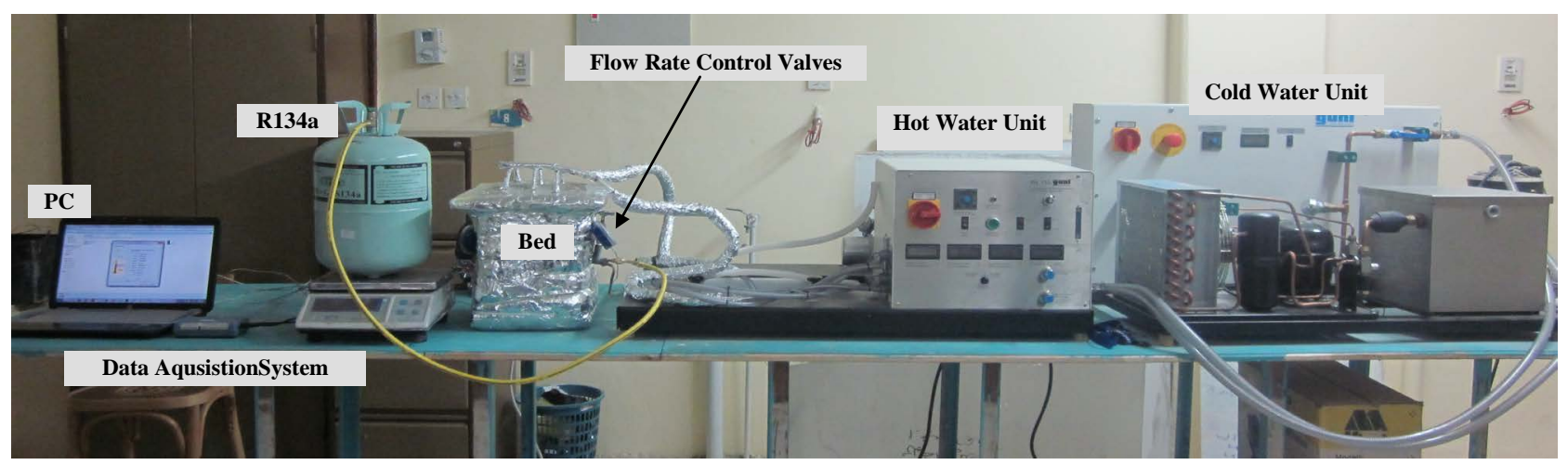

(a)

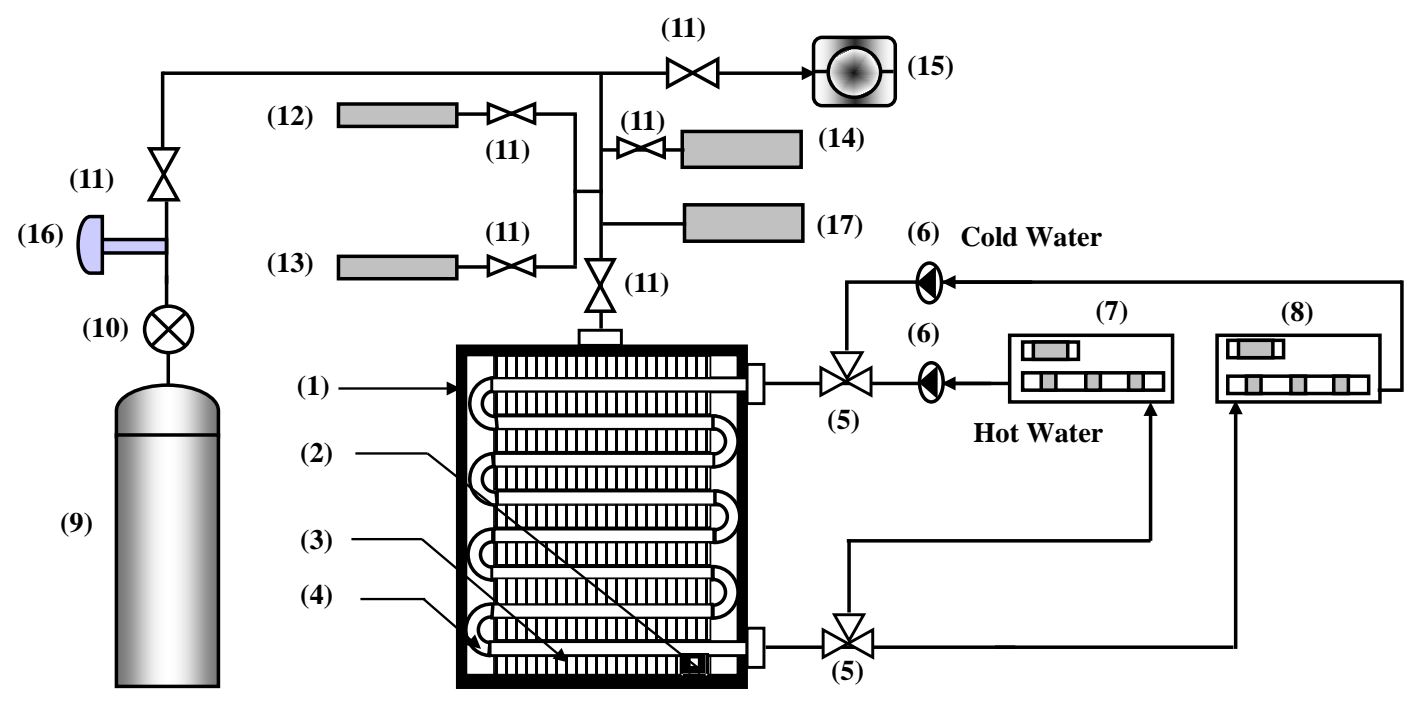

(b)

Figure 1. 1. Vacuum Chamber; 2. Adsorbent; 3. Flat Fins; 4. Tube; 5. Three Way Valve; 6. Water Pump; 7. Hot Water Unit; 8. Cold Water Unit; 9. Refrigerate Cylinder; 10. Pressure Regulator; 11. Valve; 12. Pressure Transducer; 13. Vacuum Gauge; 14. Mass Flow Control; 15. Vacuum Pump; 16. RTD Temperature Measure; 17. Temperature Measuring Unit.

Table 1. Physical properties of commercial granule activated carbon.

\begin{tabular}{cc}
\hline Properties & Value \\
\hline Bulk density $(\mathrm{g} / \mathrm{mol})$ & 0.57 \\
Apparent density $(\mathrm{g} / \mathrm{mol})$ & 0.85 \\
Density $(\mathrm{g} / \mathrm{mol})$ & 2.0 \\
Void fraction & 0.38 \\
Pore volume (mol/g) & 0.78 \\
Specific surface area $\left(\mathrm{m}^{2} / \mathrm{g}\right)$ & 950 \\
Average pore diameter $(\mathrm{mm})$ & 3.0 \\
Iodine value $(\mathrm{mg} / \mathrm{g})$ & 950 \\
\hline
\end{tabular}

water inside the system is done by using a $0.4 \mathrm{~kW}$ pump. The cooling system includes a thermostatic water tank while an electronic controller keeps the water temperature constant.

The adsorption bed is a finned tubes heat exchanger with dimensions of $280 \mathrm{~mm} \times 260 \mathrm{~mm} \times 190 \mathrm{~mm}$. It consists of 54 tubes and 85 fins where the tubes are made of copper and the fins are made of aluminium. Every tube has an inner diameter of $8 \mathrm{~mm}$ and outer diameter of $10 \mathrm{~mm}$ and every fin has a thickness of $0.35 \mathrm{~mm}$. They are wrapped with a hollow sheet to prevent the granular activated carbon (GAC) from falling and filled with $2 \mathrm{~kg}$ of the GAC. They are put in insulated stainless steel casing with dimensions $295 \mathrm{~mm} \times 280 \mathrm{~mm} \times 215 \mathrm{~mm}$ provided with pressure gauges, thermocouples and inlet and outlet tubes for water and refrigerant. The characteristics of the finned tubes heat exchanger used are listed in Table 2 .

\subsection{Instrumentation}

The experimental facility was more instrumentation devices such as pressure transducer, thermocouple and flow rate. The bed pressure was monitored by Wika A-10 pressure transducer with the accuracy of \pm 0.5 percentage 
Table 2. Characteristics of finned tubes heat exchanger.

\begin{tabular}{cc}
\hline Item & Value \\
\hline Heat exchanger dimension (mm) & $280 \times 260 \times 190$ \\
Number of tubes & 54 \\
Number of fins & 85 \\
Outer tube diameter (mm) & 10 \\
Inner tube diameter (mm) & 8 \\
Fins thickness (mm) & 0.35 \\
Casing dimension (mm) & $285 \times 280 \times 215$ \\
\hline
\end{tabular}

full scale (0 - 15 bar). The inlet and outlet temperatures and temperatures in the bed were measured with M100RTD with the accuracy of $\pm 0.06 \%$. The mass flow rates of hot and cold water measured with TUR FLO flow meters with the accuracy of $\pm 0.7 \%$. A data acquisition system consists of a DAQ-TC connected to a computer and is used to measure and record all thermocouple and pressure gage measurements. The software TRACER DQA is used to program the DAQ-TC and download and visualize the data. The digital balance was used to measure the amount of refrigerant with maximum reading 50 $\mathrm{kg}$ and accuracy about $\pm 0.001 \mathrm{~g}$.

\subsection{Procedures}

The goal of the experimental procedure is to obtain adsorption characteristics relating to the equilibrium adsorption capacity of the granule activated carbon/R-134a pair. These characteristics are important as they define the thermodynamic operation of an ideal cycle and therefore set limits with respect to performance and system size [27]. Prior to adsorption process, the GAC is placed in an oven for $12 \mathrm{~h}$. The oven temperature is kept constant at $145^{\circ} \mathrm{C}$. Before starting adsorption test the bed was evacuated using a vacuum pump to 0.05 bar. The bed was heated by using hot water circulation at $96^{\circ} \mathrm{C}$ during $6 \mathrm{~h}$, while the vacuum process is still running. The vacuum process has been occurred to take out any gases and moisture from the bed.

The bed charging (adsorption process) is starting by opening the valve between the refrigerant cylinder and the bed as shown in Figure 1(b). The pressure of the bed increased gradually with the refrigerant entering the bed. The pressure does not allow more than the saturation pressure at such a temperature $20^{\circ} \mathrm{C}$ to avoid condensation [11,12]. The valve between the refrigerant cylinder and bed was closed every $60 \mathrm{~s}$ or reached to equilibrium state. The mass of refrigerant was estimated from the difference of the test section mass at the beginning and end of each test. After the bed reaches to the equilibrium state, the bed is then heated gradually up to $100^{\circ} \mathrm{C}$ again. This process was repeated five times at different temper- atures $20^{\circ} \mathrm{C}, 27^{\circ} \mathrm{C}, 34^{\circ} \mathrm{C}, 41^{\circ} \mathrm{C}, 48^{\circ} \mathrm{C}$ and $60^{\circ} \mathrm{C}$. The equilibrium adsorption is the mass of adsorbed refrigerant divided by the mass of dry adsorbent in the adsorber.

After charging the bed by the R-134a, the system started to run by heating the bed. The heating process (desorption process) started by opening the valve between the bed and the refrigerant cylinder. The desorption process was done at different temperatures $50^{\circ} \mathrm{C}$, $60^{\circ} \mathrm{C}, 75^{\circ} \mathrm{C}, 85^{\circ} \mathrm{C}, 95^{\circ} \mathrm{C}$ and $105^{\circ} \mathrm{C}$. The experimental uncertainty of mass $\pm 0.03 \mathrm{~g}$, and the measured equilibrium adsorption has the uncertainty between $3.6 \%$ and $5.7 \%$.

The template is used to format your paper and style the text. All margins, column widths, line spaces, and text fonts are prescribed; please do not alter them. You may note peculiarities. For example, the head margin in this template measures proportionately more than is customary. This measurement and others are deliberate, using specifications that anticipate your paper as one part of the entire proceedings, and not as an independent document. Please do not revise any of the current designations.

\section{Results and discussions}

\subsection{Adsorption Equilibrium}

The Dubinin-Astakhov D-A [28,29] “Equation (1)”, was chosen to model the experimental adsorption data since it is used extensively to estimate the equilibrium uptake of GAC/R134a pair.

$$
X=X_{o} \exp \left\{-\left[\frac{R T}{E} \ln \left(\frac{p_{s}}{p}\right)\right]^{n}\right\}
$$

where $X$ is the instantaneous uptake, $X_{o}$ is the maximum uptake capacity which was estimated experimentally to be $1.92 \mathrm{~kg} / \mathrm{kg}$, and $R$ denotes the universal gas constant. The parameter $n$ is an exponential constant which estimated experimental isotherms. In the present study, the values of $E$ and $n$ were determined to $\mathrm{b} 9.574 \mathrm{~kJ} / \mathrm{mol}$ and 1.92 respectively. By knowing $X_{0}, n$ and $E$ "Equation (1)", could be written in form of "Equation (2)".

$$
X=X_{o} \exp \left\{-\left[0.0008686 \times T \ln \left(\frac{p_{s}}{p}\right)\right]^{1.92}\right\}
$$

It is well known that the adsorption cooling potential of adsorbent is determined by both maximum adsorption capacity and the rate of adsorption and desorption, among other parameters. These parameters are weight of the bed, temperature and pressure which measured at every $90 \mathrm{~s}$. Figure 2 shows experimental results for the adsorption capacity of GAC/R-134a pair against relative pressure at six different temperatures. As can be seen from Figure 2, the equilibrium adsorption capacity of temperature $20^{\circ} \mathrm{C}$ is considerably larger than those of other temperatures. Also the maximum adsorption capac- 
ity that could be reached is $1.92 \mathrm{~kg} / \mathrm{kg}$ at $20^{\circ} \mathrm{C}$ adsorption temperature with an interval time of $1200 \mathrm{~s}$. The figure shows the adsorption capacity rises rapidly in the first $110 \mathrm{~s}$ and then has a slow progress and the adsorption capacity approaches a limiting value as the relative pressure approaches unity. This order is corresponding to that of the lower vacuum pressure in the bed at starting process.

Figure 3 shows the isobaric adsorption GAC/R-134a pair at four different pressures of 1, 2, 4, 6 and 8 bar corresponding to the saturated temperature of R134a. It is observed that the isobaric adsorption is the maximum value at low temperature and then decreases with the increase of temperature.

The relation between desorption capacity during desorption process and relative pressure is shown in Figure 4. The desorption process was measured at six different temperatures, $50^{\circ} \mathrm{C}, 60^{\circ} \mathrm{C}, 75^{\circ} \mathrm{C}, 85^{\circ} \mathrm{C}, 95^{\circ} \mathrm{C}$ and $105^{\circ} \mathrm{C}$. It can be noticed that the instantaneous desorption capacity decreases rapidly at the start of the desorption process. This is due to that the relative pressure is high of the bed at the start of the desorption process. After that, the desorption capacity decreases slowly with decreases in the relative pressure.

The isotherms obtained from the present study are compared with the results obtained by Saha et al. [5] and Askalany et al. [11] and the results of the comparison are shown in Figure 5. It is observed that the maximum uptake that Saha et al. [5] and Askalany et al. showed [11] is lower than that of the present study. This is due to increasing of the heat transfer area achieved by using a finned tubes heat exchanger.

Figure 6 shows the adsorption isotherms for GAC/ $\mathrm{R}-134$ a pair over the temperature range of $10^{\circ} \mathrm{C}-95^{\circ} \mathrm{C}$. The isotherms are expected by using D-A "Equation (2)" where the equilibrium pressure for different values of equilibrium adsorption capacity, $X$ at constant temperature $[11,12]$. The relation between pressure and temperature at different adsorption capacities could be predicted by using "Equation (2)", as shown in Figure 7. This figure is known as P-T-X diagram [5]. It is observed that, at certain equilibrium pressure, the equilibrium adsorption capacity decreases with increasing adsorbent temperature. This is due to that the heat of adsorption is generated and hence the adsorbent temperature increases during the adsorption process. The generated heat is usually removed by using water as a cooling fluid. Therefore, it is important to enhance the heat transfer characteristics of the adsrober so that it can achieve by using a finned tubes heat exchanger, where the heat transfer area increases.

\subsection{Heat of Adsorption}

The isosteric heat is defined as the heat of desorption under constant adsorption capacity [5]. The isosteric heat of adsorption for GAC/R-134a pair can be expressed by using the following Clausius-Clapeyron equation [5,11, $12]$ is shown.

$$
R \frac{\partial \ln p}{\partial(1 / T)}=-Q_{s t}
$$

where $Q$ is the isosteric heat adsorption $\left(\mathrm{kJ} / \mathrm{kg}_{\mathrm{w}}\right)$,

$$
h_{f g}+E\left\{\left[\ln \left(\frac{X_{o}}{X}\right)\right]^{1 / n}+a\left(\frac{T}{T_{c}}\right)^{b}\right\}=Q_{s t}
$$

where $E$ is the characteristic energy which is equal to $98.848 \mathrm{~kJ} / \mathrm{kg}$ and $T_{c}$ is the critical temperature for R-134a it is equal to $100.9^{\circ} \mathrm{C}$.

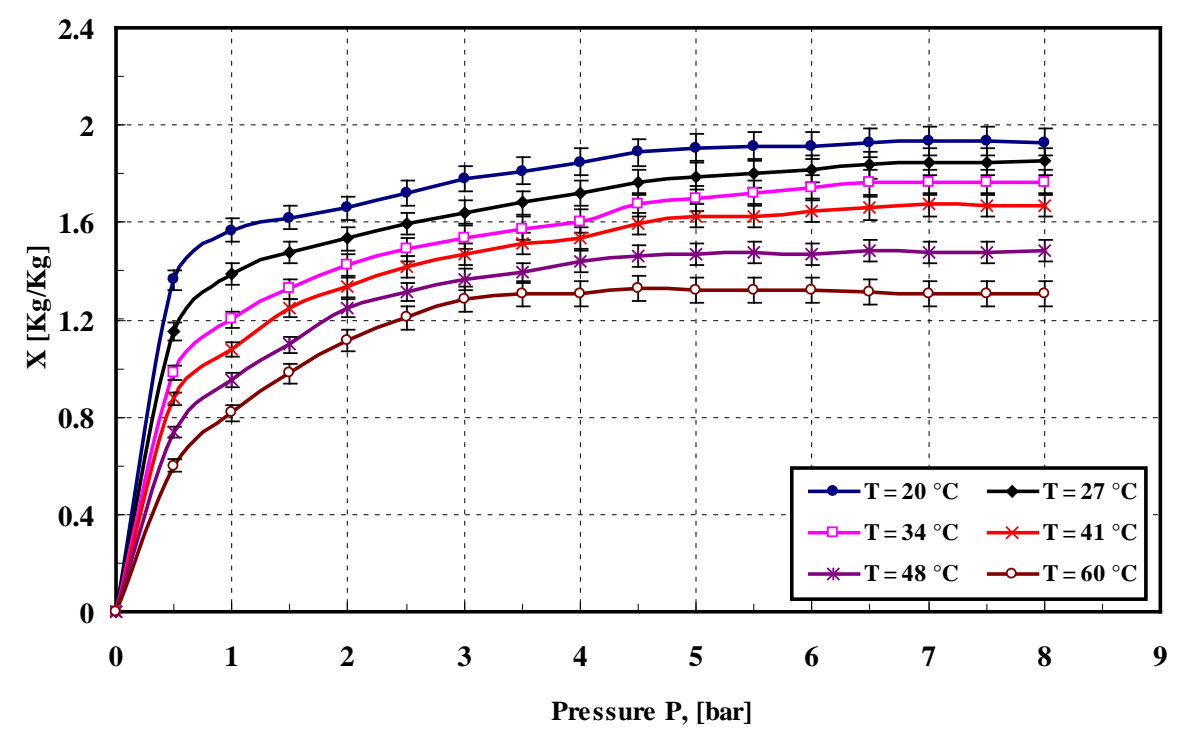

Figure 2. Adsorption isotherm of R-134a on granular activated carbon. 


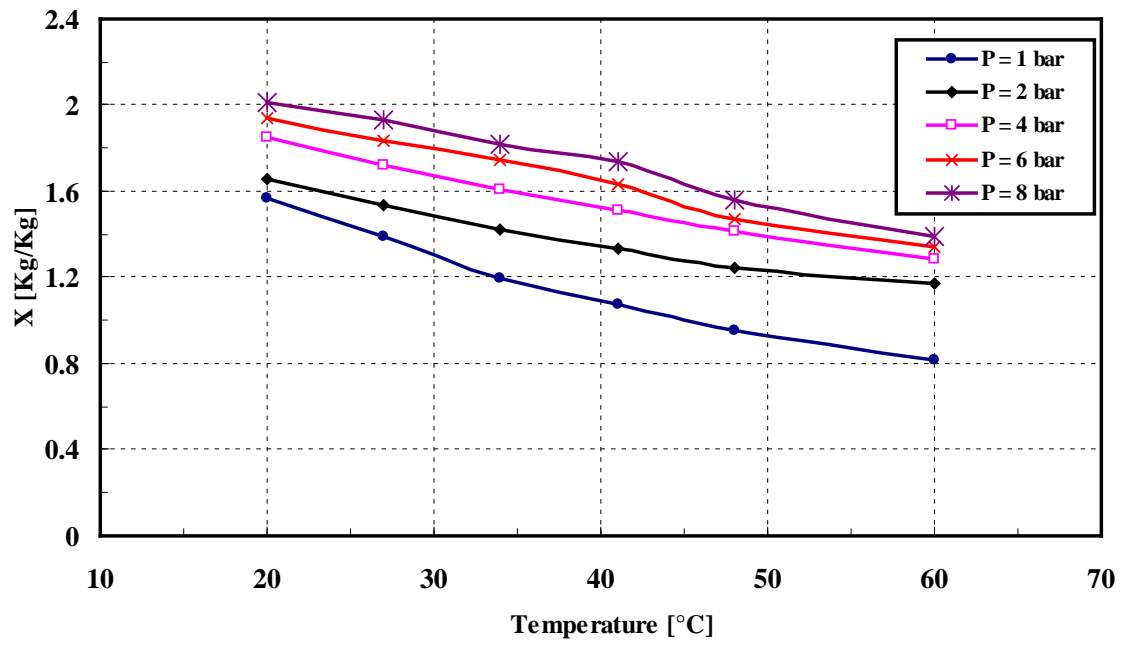

Figure 3. Effect of pressure on adsorption isotherm of R-134a on granular activated carbon.

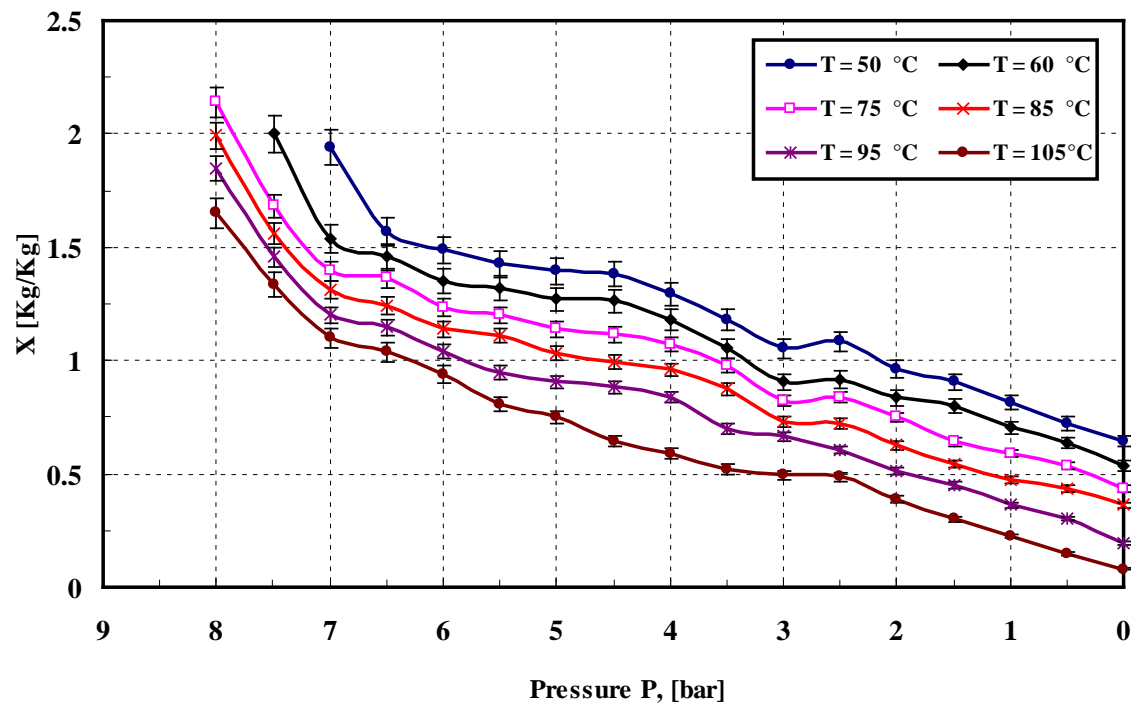

Figure 4. Desorption isotherm of R-134a on granular activated carbon.

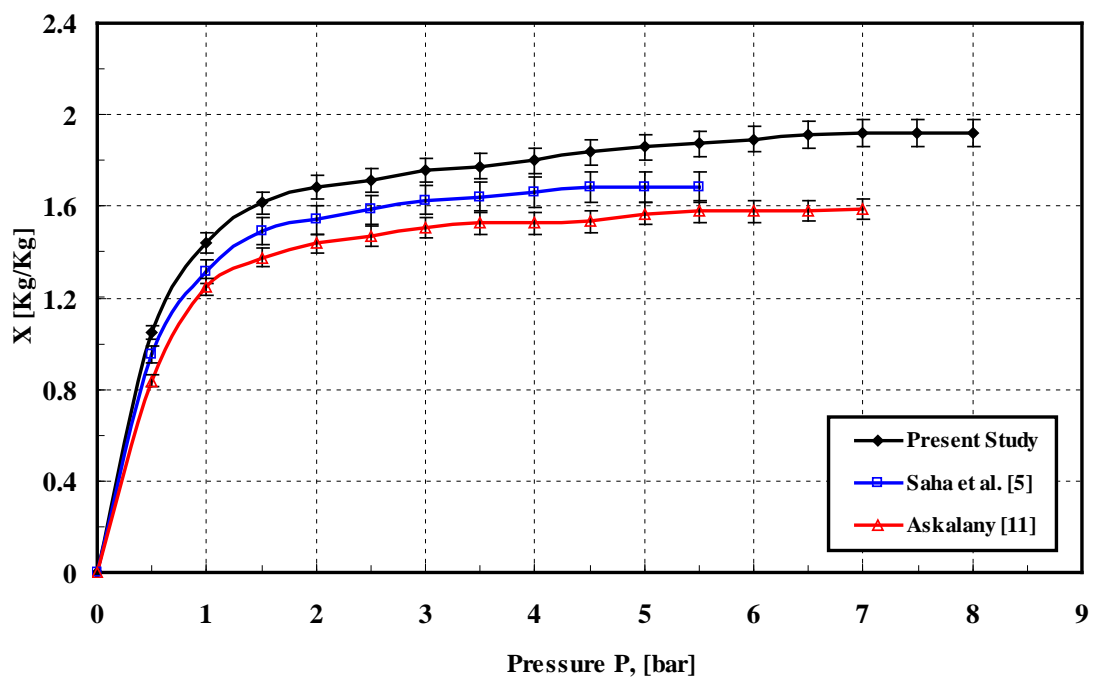

Figure 5. Adsorption isotherm of R-134a on granular activated carbon at $25^{\circ} \mathrm{C}$. 


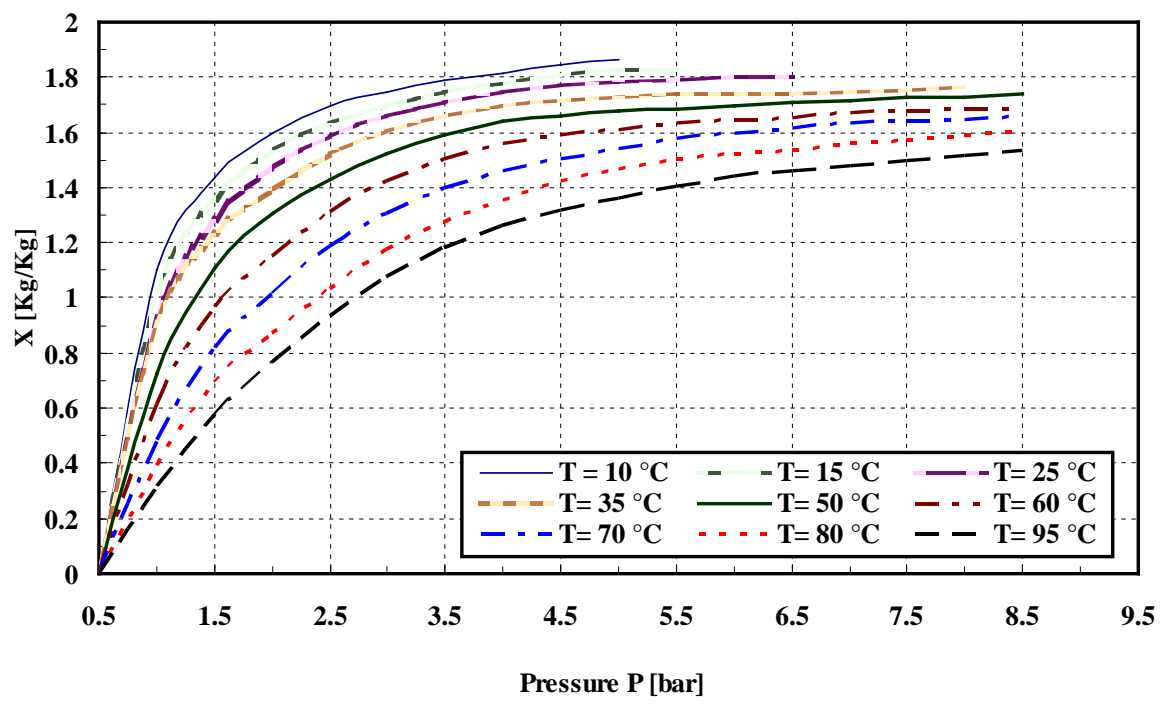

Figure 6. Adsorption equilibrium of GAC/R-134a pair.

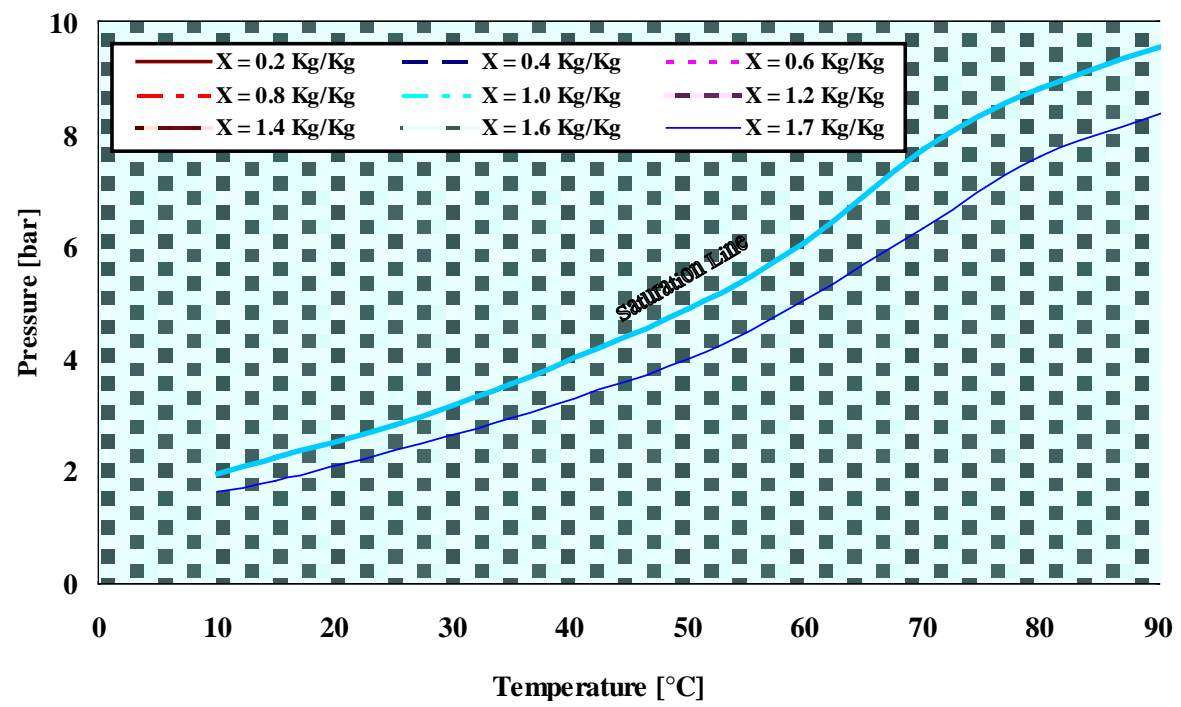

Figure 7. P-T-X diagrams of the GAC/R-134a pair.

El-Sharkawy et al. [5] and Habib et al. [10] approximated the values of the constants $a$ and $b$ for R-134a of equal 1.81 and 6.25 respectively. Using the above values, the "Equation (4)", could be written in the following form;

$$
Q_{s t}=h_{f g}+9.574\left\{\left[\ln \left(\frac{1.92}{X}\right)\right]^{0.55}+1.81\left(\frac{T}{374.05}\right)^{6.25}\right\}
$$

From "Equation (5)", the variation of isosteric heat of adsorption with adsorption capacity at different temperatures is shown in Figure 8. One observes from this figure that the isosteric of adsorption decreases with increasing adsorbate uptake of R-134a. In addition the temperatures of bed have more effect on isosteric heat, where the ma- ximum value of isosteric heat obtained with low temperature at $20^{\circ} \mathrm{C}$.

Similar results were recommended by Saha et al. [5] where the adsorption characteristics and heat of adsorption of R134a were measure on activated carbon. Saha et al. [5] illustrated that the Maxsorb III consists mainly of micropores with different width adsorbs rapidly onto sites and R-134a of high energy, and as adsorption progresses, molecules adsorb onto sites of decreasing energy.

The R-134a molecules first penetrate into narrow pores of Maxsobr III, resulting in a stronger interaction between adsorbate and Maxsorb III. This implies a higher value of isosteric heat of adsorption at lower loading. After completely filling the smaller pores, R-134a molecules are gradually accommodated in larger pores, in 


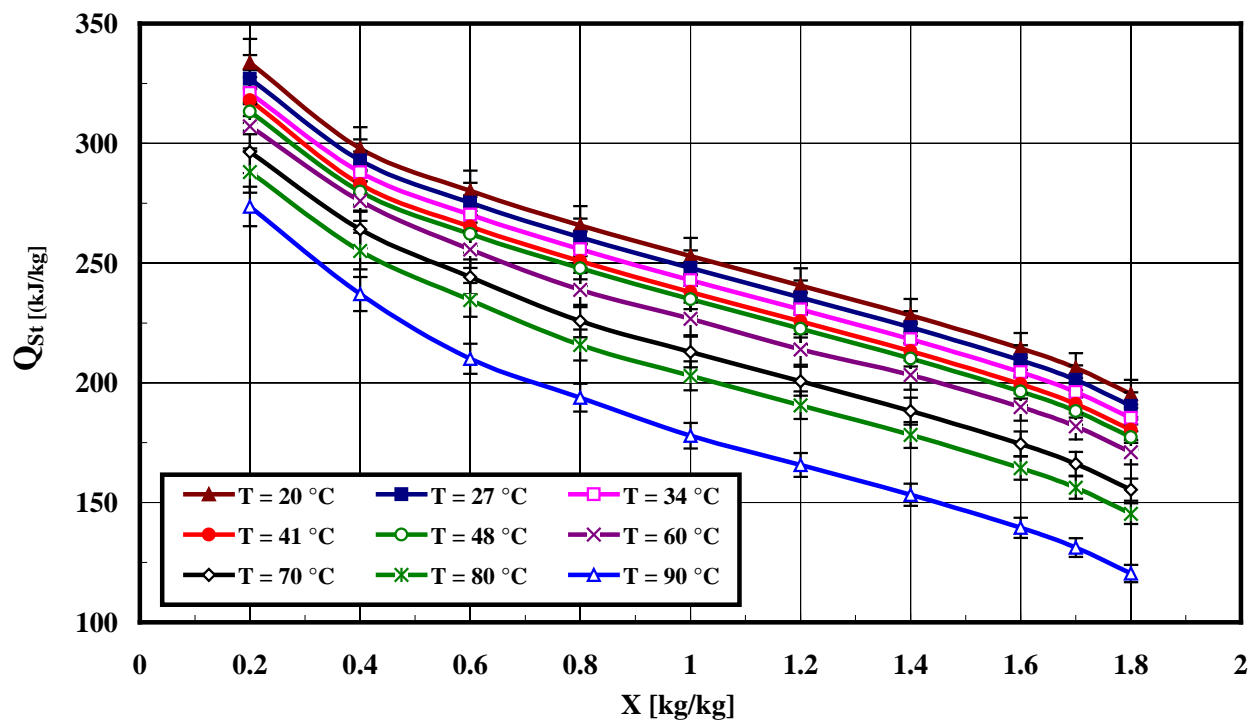

Figure 8. Isosteric heat of adsorption at different temperature.

which the adsorption affinity becomes weaker $[5,12]$. Therefore a monotonic decrease in isosteric heat of adsorption as a function of adsorbate R-134a uptake.

\section{Conclusions}

The adsorption capacity (X) of R-134a on a granular activated carbon for adsorption/desorption process has been experimentally studied. The bed was designed and built with finned tubes heat exchanger to increase the heat transfer area. The experiments were conducted over a temperature range from $20^{\circ} \mathrm{C}$ to $60^{\circ} \mathrm{C}$ and pressure up to 10 bars. The data were correlated with Dubinin-Astakhov (D-A) equation corresponding adsorption/desoption process. The present results are compared with the results performed by other researchers.

The main remarkable points can be summarized as follows:

1) The adsorption capacity per kg of adsorbent increases rapidly with increasing relative pressure at the beginning of the adsorption process.

2) The maximum adsorption capacity uptake is 1.92 $\mathrm{kg} / \mathrm{kg}$ at $20^{\circ} \mathrm{C}$ after $1200 \mathrm{~s}$.

3) The maximum value of adsorption capacity decreases to $1.31 \mathrm{~kg} / \mathrm{kg}$ with the increase of adsorbent temperature at $60^{\circ} \mathrm{C}$.

4) The maximum adsorption capacity increases about 9.62\% compared with the other researches', because the heat transfer area increases in bed at $25^{\circ} \mathrm{C}$.

5) The isosteric heat of adsorption varied from 120 to $340 \mathrm{~kJ} / \mathrm{kg}$ for adsorption capacities ranging from 0.2 to $1.8 \mathrm{~kg} / \mathrm{kg}$.

6) The accurate adsorption isotherms and heat of adsorption data of R-134a on granular activated carbon are essential in designing thermally driven pressured bed ad- sorption chillers based on assorted pair.

\section{REFERENCES}

[1] F. Meuiner, "Theoretical Performances of Solid Adsorbent Cascading Cycles Using the Zeolite-Water and Active Carbon-Methanol Pairs: Four Case Studies,” Heat Recovery System, Vol. 6, No. 6, 1986, pp. 491-498. http://dx.doi.org/10.1016/0198-7593(86)90042-1

[2] F. Meuiner, "Solid Sorption Heat Powered Cycles for Cooling and Heat Pumping Applications," Applied Thermal Engineering, Vol. 18, No. 9-10, 1998, pp. 715-729. http://dx.doi.org/10.1016/S1359-4311(97)00122-1

[3] I. I. El-Sharkawy, K. Kuwahara, B. B. Saha, S. Komyama and K. C. Ng, "Experimental Investigation of Activated Carbon Fibers/Ethanol Pairs for Adsorption Cooling System Application,” Applied Thermal Engineering, Vol. 26, No. 8-9, 2006, pp. 859-865.

http://dx.doi.org/10.1016/j.applthermaleng.2005.10.010

[4] L. W. Wang, R. Z. Wang and R. G. Oliveira, "A Review on Adsorption Working Pairs for Refrigeration," Renewable and Sustainable Energy Review, Vol. 13, No. 3, 2009, pp. 518-534. http://dx.doi.org/10.1016/j.rser.2007.12.002

[5] B. B. Saha, K. Habib, I. I. El-Sharakawy and S. Koyama, "Adsorption Characteristics and Heat of Adsorption Measurements of R134a on Activated Carbon,” International Journal of Refrigeration, Vol. 32, No. 7, 2009, pp. 15631569. http://dx.doi.org/10.1016/j.ijrefrig.2009.03.010

[6] D. J. Miles and S. V. Shelton, "Design and Testing of a Solid Sorption Heat Pump System,” Applied Thermal Engineering, Vol. 16, No. 5, 1996, pp. 389-394. http://dx.doi.org/10.1016/1359-4311(95)00021-6

[7] D. C. Wang, Z. Z. Xia and J. Y. Zhu, "Design and Performance Prediction of a Novel Zeolite-Water Adsorption Air Condition," Energy Conversion and Management, Vol. 47, No. 5, 2006, pp. 590-610. 
http://dx.doi.org/10.1016/j.enconman.2005.05.011

[8] R. Z. Wang, J. P. Jia, Y. H. Zhu, Y. Teng, J. Y. Wu, J. Cheng and Q. B. Wang, "Study on a New Solid Adsorption Refrigeration Pair: Activated Carbon Fiber-Methanol Pair," Transactions on ASME, Vol. 119, No. 3, 1997, pp. 214-218.

[9] Y. Hamamoto, K. C. A. Alam, B. B. Saha, S. Koyama, A. Akisawa and T. Kashiwagi, "Study on Adsorption Refrigeration Cycle Utilizing Activated Carbon Fibers. Part 1 Adsorption Characteristics," International Journal of Refrigeration, Vol. 29, No. 2, 2006, pp. 305-314. http://dx.doi.org/10.1016/j.ijrefrig.2005.04.008

[10] K. Habib, B. B. Saha, A. Charkraborty and S. Koyama, "Performance Evaluation of Combined Adsorption Refrigeration Cycles," International Journal of Refrigeration, Vol. 34, No. 1, 2011, pp. 129-137. http://dx.doi.org/10.1016/j.ijrefrig.2010.09.005

[11] A. A. Askalany, M. Salem, I. M. Ismail, A. H. H. Ail and M. G. Morsy, "Experimental Study on Adsorption-Desorption Characteristics of Granular Activated Carbon/ R134a Pair,” International Journal of Refrigeration, Vol. 35, No. 3, 2012, pp. 494-498. http://dx.doi.org/10.1016/j.ijrefrig.2011.04.002

[12] A. A. Askalany, B. B. Saha, M. S. Ahmed and I. M. Ismail, “Adsorption Cooling System Employing Granular Activate Carbon-R134a Pair for Renewable Energy Applications,” International Journal of Refrigeration, Vol. 36, No. 3, 2013, pp. 1037-1044. http://dx.doi.org/10.1016/j.ijrefrig.2012.11.009

[13] B. S. Akkimaradi, M. Prasad, P. Dutta and K. Srinivasan, "Adsorption of 1,1,1,2-Tetrafluoroethane on Activated Charcoal," Journal of Chemical Engineering Data, Vol. 46, No. 2, 2001, pp. 417-422. http://dx.doi.org/10.1021/je000277e

[14] M. Pons and J. J. Guilleminot, "Design of an Experimental Solar Powered Adsorption Ice Maker,” ASME JJSE, Vol. 108, No. 4, 1986, pp. 332-337.

[15] L. L. Vasiliev, D. A. Mishkinis A. A. antukh and L. L. J. Vasiliev, "Solar-Gas Solid Sorption Heat Pump," Applied Thermal Engineering, Vol. 21, No. 5, 2001, pp. 573-583. http://dx.doi.org/10.1016/S1359-4311(00)00069-7

[16] L. L. Vasliev, "Solar Sorption Refrigeration with Dual Sources of Energy," ISHPC'02 Proceedings of the International Sorption Heat Pump Conferences, Shanghai, 2427 September 2002, pp. 26-33.

[17] N. D. Banker, P. Dutta, P. Prasad and K. Srinivasan, “Activated Carbon + HFC 134a Based Two Stage Thermal Compression Adsorption Refrigeration Using Low Grade Thermal Energy Sources,” Applied Thermal Engineering, Vol. 29, No. 11-12, 2009, pp. 2257-2264. http://dx.doi.org/10.1016/j.applthermaleng.2008.11.006

[18] N. D. Banker, P. Dutta, P. Prasad and K. Srinivasan, "Development and Transient Performance Results of a Single Stage Activated Carbon-HFC 134a Closed Cycle Adsorption Cooling System," Applied Thermal Engineering, Vol. 30, No. 10, 2010, pp. 1126-1132. http://dx.doi.org/10.1016/j.applthermaleng.2010.01.027

[19] W. S. Chang, C. C. Wang and C. C. Shieh, "Experimental
Study of a Solid Adsorption Cooling System Using FlatTube Heat Exchangers as Adsorption Bed,” Applied Thermal Engineering, Vol. 27, No. 13, 2007, pp. 2195-12199. http://dx.doi.org/10.1016/j.applthermaleng.2005.07.022

[20] F. Watanabe, J. Kozuka, M. Ito and M. Hasatani, "Heat and Mass Transfer in Super Active Carbon/Ethanol Adsorption Heat Pump with a Packed Bed Type Adsorber,” Heat Transfer Japan Research, Vol. 25, No. 7, 1996, pp. 466-475.

http://dx.doi.org/10.1002/(SICI)1520-6556(1996)25:7<46 6::AID-HTJ5>3.0.CO;2-V

[21] E. C. Boelman, B. B. Saha and T. Kashiwagi, "Experimental Investigated of a Silica Gel Water Adsorption Refrigeration Cycle-The Influence of Operating Conditions on Cooling Output and COP,” ASHRA Transactions, Vol. 101, No. 2, 1995, pp. 358-366.

[22] M. Ito, F. Watanabe and M. Hasatani, "Cold Energy Generation Characteristics of Adsorption Heat Pump Using Direct Heat Exchanger Module,” Kagaku Kougaku Ronbunshu, Vol. 22, No. 4, 1996, pp. 926-929.

http://dx.doi.org/10.1252/kakoronbunshu.22.926

[23] Y. H. Zhang, “Adsorption Function,” Publishing House of Scientific and Technology Literature in Shanghai, Shanghai, 1989.

[24] R. Tiller-Roth and H. D. Baehr, “An International Standard Formulation for the Thermodynamic Properties of 1,1,1,2-Tetrafluoroethane (HCF-134a) from $170 \mathrm{~K}$ to 455 K and Pressure up to $70 \mathrm{MPa}$," Journal Physics Chemistry Reference Data, Vol. 23, No. 5, 1994, pp. 657-729. http://dx.doi.org/10.1063/1.555958

[25] L. W. Wang, J. Y. Wu, R. Z. Wang Y. X. Xu and S. G. Wang, "Experimental Study of a Solidified Activated Carbon-Methanol Adsorption Ice Maker," Applied Thermal Engineering, Vol. 23, No. 12, 2003, pp. 1453-1462. http://dx.doi.org/10.1016/S1359-4311(03)00103-0

[26] L. W. Wang, J. Y. Wu, R. Z. Wang, Y. X. Xu, S. G. Wang and X. R. Li, "Study of the Performance of Activated Carbon-Methanol Adsorption Systems Concerning Heat and Mass Transfer," Applied Thermal Engineering, Vol. 23, No. 13, 2003, pp. 1605-1617.

http://dx.doi.org/10.1016/S1359-4311(03)00104-2

[27] I. Solmus, C. Yamali, B. Kaftanoğlu, D. Baker and A. Çağlar, "Adsorption Properties of a Natural Zeolite-Water Pair for Used in Adsorption Cooling Cycles," Applied Energy, Vol. 87, No. 6, 2010, pp. 2062-2067. http://dx.doi.org/10.1016/j.apenergy.2009.11.027

[28] S. L. Li, J. Y. Wu, Z. Z. Xia and R. Z. Wang, "Study on the Adsorption Isosteres of the Composite Adsorbent $\mathrm{CaCl}_{2}$ and Expanded Graphite,” Energy Conversion and Management, Vol. 52, No. 2, 2001, pp. 1501-1506. http://dx.doi.org/10.1016/j.enconman.2010.10.015

[29] I. I. El-Sharkawy, B. B. Saha, S. Koyama and K. Srinivasan, "Isosteric Heats of Adsorption Extracted from Experiments of Ethanol and HFC 134a on Carbon Based Adsorbents," International Journal of Heat and Mass Transfer, Vol. 50, No. 5-6, 2007, pp. 902-907. http://dx.doi.org/10.1016/j.ijheatmasstransfer.2006.08.03 $\underline{6}$ 


\section{Nomenclature}

a: Constant, [-]

$b$ : Constant, [-]

COP: Coefficient of Performance, [-]

$E$ : Characteristic energy, $\mathrm{J} / \mathrm{mol}$

$h_{f g}$ : latent heat, $\mathrm{kJ} / \mathrm{kg}$

$n$ : Exponential constant, [-]

$P$ : pressure, bar

$Q_{s t}$ Isosteric heat adsorption, $\mathrm{kJ} / \mathrm{kgw}$

$R$ : Universal gas constant, $\mathrm{mol} / \mathrm{K}$

$T$ : Temperature, $\mathrm{K}$

$T_{c}$ : Critical temperature for R-134a, $\mathrm{K}$

$X$ : Adsorption mass capacity, $\mathrm{kg}_{\mathrm{R} 134 \mathrm{a}} / \mathrm{kg}_{\text {carbon }}$

$X_{o}$ : Maximum adsorption mass capacity, $\mathrm{kg}_{\mathrm{R} 134 \mathrm{a}} / \mathrm{kg}_{\text {carbon }}$ 